\begin{tabular}{c} 
Volume and Issues Obtainable at Center for Sustainability Research and Consultancy \\
Journal of Business and Social Review in Emerging Economies \\
ISSN: 2519-089X (E): 2519-0326 \\
Volume 6: No. 1, March 2020 \\
CSRᄃ \\
Journal homepage: www.publishing.globalcsrc.org/jbsee \\
\hline
\end{tabular}

\title{
The Moderating Effect of Employee Satisfaction on the Relationship of Goal- Setting and Purposes, Fairness and Rating Scale Format with Employee Job Performance
}

\author{
${ }^{1}$ Muhammad Asad Khan, ${ }^{2}$ Altaf Hussain, ${ }^{3}$ Mohammad Hanif Khan \\ ${ }^{1}$ PhD Scholar, Universiti Tun Hussein Onn (UTHM) Malaysia. asadkhanbte06@ gmail.com \\ ${ }^{2}$ Assistant Professor, Department of Commerce and Management Sciences, University of \\ Malakand, Khyber Pakhtunkhwa, Pakistan. altafhussain@uom.edu.pk \\ ${ }^{3}$ Lecturer, Department of Tourism and Hotel Management, University of Malakand, Khyber \\ Pakhtunkhwa, Pakistan. hanifyousafzai@uom.edu.pk
}

\begin{tabular}{l} 
ARTICLE DETAILS \\
\hline History \\
Revised format: February 2020 \\
Available Online: March 2020
\end{tabular}

Keywords

Goal-setting and purposes, fairness, rating scale format, employee satisfaction, employee job performance

JEL Classification:

J59, J28, E49

\section{ABSTRACT}

The aim of this article is to explore the moderating effect of employee satisfaction on the relationship of goal-setting and purposes, fairness and rating scale format with employee job performance in the academic setting. Data were collected through survey questionnaire from 300 employees working in six public sector universities of KP, Pakistan. Multiple regression analysis has been used to test the hypothesis. The dimensions of the performance appraisal were found to be significantly correlated to employee job performance and employee satisfaction played a crucial role in moderating this relationship. Potential reasons and suggestions for managers and employees are discussed. The paper adds to the current pool of knowledge on the links among goal-setting and purposes, fairness, rating scale format, employee satisfaction and employee job performance. Various facets of these constructs were analyzed, so as to give an extensive and more ample understanding of the determinants that influence employer and employees.

(C) 2020 The authors, under a Creative Commons AttributionNonCommercial 4.0

Corresponding author's email address: asadkhanbte06@ gmail.com

Recommended citation: Khan, M.A., Hussain, A., \& Khan, M.H.(2020). The Moderating Effect of Employee Satisfaction on the Relationship of Goal-Setting and Purposes, Fairness and Rating Scale Format with Employee Job Performance. Journal of Business and Social Review in Emerging Economies, 6(1), 309-320

DOI: $10.26710 /$ jbsee.v6i1.1066

\section{Introduction}

Human resource campaigners are finding modern ways to improve job performance of employees in every field. Research of the human resource contributions has proposed new scopes in this regard (R. Khan, 2014). The same researcher has verified a model in this respect and established that human resource intervention have significant impact in the process of enhancing employee job performance and organizational performance. It is suggested that goal-setting should also be tested in a relationship with employee job performance (R. Khan, 2014). While, Knight, Durham, and Locke (2001) have concluded 
from his study that goal-setting and employee output have strong relationship and used as a source of efficiency in the organization. The core purpose of performance appraisal is to get the purposes that is, goal setting and employee improvement and satisfaction base evaluation system of employee job performance (Lawler III, Benson, \& McDermott, 2012). If any performance appraisal has clear goals and purposes it looks to be highly satisfactory (Sahai \& Srivastava, 2012) then those who donot have. In the same task, fairness of performance appraisal also affects employee attitude, behaviour and performance significantly (Kaleem, Jabeen, \& Twana, 2013). It has noted with concern that every performance appraisal will be considered failed if employees feel unfairness and dissatisfaction and their performance also decreases to greater extent (Kaleem et al., 2013). Fairness and employee job performance has a strong relationship because if rater does fair assessment of his subordinate ultimately he will be satisfied and motived to perform better (Kaleem et al., 2013). There is dearth of research to study fairness of performance appraisal system with employee job performance in context of Pakistan (Ishaq, Iqbal, \& Zaheer, 2009). Satisfaction is directly related to job performance in a sense that those employees who have high level of satisfaction are found to be high performer and vice versa (Palaiologos, Papazekos, \& Panayotopoulou, 2011). Now the researchers have emphasized on the accurate and fair performance appraisal assessment of employee job performance by improving rating scale format in order to minimize rater biasness and increase employee satisfaction with measurement process (Zheng, Zhang, \& Li, 2012). The basic aim of scheming behaviourally anchored rating scale was to develop the current performance rating criteria about measuring employee job performance accurately (Landy \& Farr, 1983). A previous research has identified that behavioural observation scale format will enhance positivity in rater as well as satisfaction level of employees. Employees have given away higher satisfaction towards behavioural observation format because this rating format is subjected to be more lenient, precise, objective and free of biases to greater extent comparatively than others at hand (Tziner \& Kopelman, 2002). In public sector organization of Pakistan it is needed to have such a valid rating scale format of performance appraisal system that covers all the credentials and aspects for judging employee job performance (Zia-ur-Rehman, Faisal, \& Khan, 2015). Satisfaction of employees does not occur automatically but specific goal and purposes, fairness and valid rating scale format of performance appraisal system influencing employee job performance (Iqbal, Ahmad, Haider, \& Batool, 2013).

This study is an attempt to find out the significant relationship between performance appraisal and its dimensions and employee job performance with having the moderating effect of employee satisfaction in academic sector of Pakistan.

\section{Literature review}

\subsection{Goal setting and purposes}

It is established that goal setting of performance appraisal has been studied over the past three decades worldwide (Teo \& Low, 2016). Goal setting is a formal program of setting specific quantifiable performance goals for employees for the very purpose to share the common targets of enhancing employee satisfaction and performance (Teo \& Low, 2016). According to (Iqbal, Ahmad, \& Haider, 2013) it is recognized internationally that human resource management research of performance appraisal has attained the explicit purposes but remain failed to achieve the other purposes like improving employee job performance and satisfaction. In recent past universities also concentrated on these aspects of performance appraisal system to get benefit from its pre-defined goals and purposes (Cintrón \& Flaniken, 2011). In the same line of literature, Simmons (2002) has also stressed that top management of universities should also focus on the development of their own performance appraisal system which is established on clear goals and purposes which result into the enhancement of employee satisfaction and performance. Goal is a standard for measuring employee satisfaction and committed employees are reported to be high goal achiever and best performer within the organization (Teo \& Low, 2016). Several researchers have proved that goal setting theory uses has maximized employee effort, satisfaction and performance level (Terpstra \& Rozell, 1994). It is proved statistically that goal setting is found to enhance employee job performance and productivity. So, through adequate goal setting both individual job performance and organizational performance enhances (Terpstra \& Rozell, 1994). 
On the basis of above literature we can propose that:

HI: Goal setting and purposes has a significant effect on employee job performance.

\subsection{Fairness}

The literature exposes that in the past researchers were focused their attention on rating scale improvement but with the passage of time, fairness and satisfaction of performance appraisal has drawn focus of researchers (Ikramullah, Shah, Hassan, Zaman, \& Khan, 2011). It has been identified from research that sound performance appraisal system will subject to failure if it is not accepted by both the supervisor and employees. As a consequence fairness is the integral part of performance appraisal system to be successful (Jawahar, 2007). Majority of the research has been conducted in western countries and very scant studies have investigated the association of fairness with employee satisfaction and job performance in Asian cultural context (Sudin, 2011). We still have less knowledge that how fairness of performance appraisal influence employee satisfaction (Sudin, 2011). According to Getnet, Jebena, and Tsegaye (2014) nowadays the growing concern of majority of employees in various organizations is the fairness at work settings. This problem specifically connected to the performance appraisal system and is crucial to administration in improving employee job performance (Getnet et al., 2014). Most of the studies have revealed that fairness of performance appraisal is positively and significantly related with employee job performance (Abbas, 2014; Muhammad Asad khan, 2018; Selvarajan \& Cloninger, 2009).

On the basis of above discussion we can hypothesize that:

H2: Fairness has a significant effect on employee job performance.

\subsection{Rating scale format}

Rating scale format has been used to enhance the psychometric properties of performance appraisal to accurately assess employee job performance. one useful attempt was done by to used Behaviourally anchored rating scales to improve rating accuracy and avoid rating errors to some extent (Smith \& Kendall, 1963). These scholars have attempted to alter numerical frequency with actual examples of work behaviour. According to Embi and Choon (2014) now performance appraisal research has concentrated on the improvement of rating scale format to minimize rating errors and develop rating accuracy. Previous studies showed that performance appraisal accuracy was thoroughly examined because fair appraisal was accepted by employee due to fairness and better accurate performance ratings and respond with high job performance (Embi \& Choon, 2014). Performance appraisal accuracy has been studied heavily to improve job performance and it is possible merely when rater focuses on the improvement of rating scales and consequent upon rating error (DeNisi, 2011). The body of studies formulated better rating scales that maximize rating accuracy in order to employees get satisfied and improve their performance (DeNisi, 2011). Rating scale accuracy means how to minimize rating errors that is graphing rating scale or behaviourally anchored rating scales and offer training to the supervisors to decrease errors in their performance appraisal sessions (DeNisi, 2011; Smith \& Kendall, 1963). However, there is no such proofs on the ground that which rating scale format is better than others (Landy \& Farr, 1983). Most of the scholars have identified that rating scale format influence satisfaction and job performance regarding their overall performance (Djurdjevic \& Wheeler, 2014; Getnet et al., 2014).

On the basis of the above literature we can assume this hypothesis:

H3: Rating scale format has a significant effect employee job performance.

\subsection{Employee job performance}

Performance can be defined as something connected to the actions in a work setting and also comprise of judgment and assessment methods (Ilgen \& Schneider, 1991). Those actions which is measurable and examined are imitated as performance (Campbell, McCloy, Oppler, \& Sager, 1993). High level of job performance advances an organization and has higher opportunities for employees career development instead of those who are low performer (Iqbal, Ahmad, Haider, et al., 2013). Every organization acquired high performances of its workforce in order to compete in the global market and encounter their goals and objectives (Ikramullah, Van Prooijen, Iqbal, \& Ul-Hassan, 2016). Performance appraisal stresses on the 
performance outputs not on personal attributes. According to Kline and Sulsky (2009) performance appraisal that has no validity and reliability regarding measurement criteria is found to be biased and badly affected employee performance. M. F. U. Khan (2013) argued that employee job performance has increased by setting accurate performance criteria. It is evident that performance appraisal has been used for long time to enhance employee job performance and organizational performance (Pulakos, 2004). A considerable amount of studies have been conducted on the relationship of performance appraisal and employee job performance worldwide but still there is need of research on such relationship in the context of academic sector in Pakistan (Muhammad Asad khan, 2018; Shahzad, Bashir, \& Ramay, 2008). Several scholars have examined a positive association between these two variables (Rahman, 2012; Zeb, Abdullah, \& Javaid, 2018).

\subsection{Employee satisfaction as a moderator}

Employee satisfaction affects the relationship between performance appraisal and productivity (Keeping \& Levy, 2000). Employee satisfaction involves satisfaction with appraisal system satisfaction with fairness and objectivity of rating system (Cintrón \& Flaniken, 2011; Jawahar, 2007). If employees rely on that performance appraisal system is fairly practiced in work settings resultantly employees are more likely to be satisfied and accepts the outcomes achieved regarding performance even if the outcomes are not adequate (Cintrón \& Flaniken, 2011). Employee satisfaction is an important predictor in the performance evaluation process in the building of this system effective but if it is not biased, inaccurate and used valid rating criteria for improving employee job performance (Getnet et al., 2014). Initially goal setting should cover the aspirations of appraisers and measured that would not reflect dissatisfaction with the already set goals and objectives of the organization (Ikramullah et al., 2016). Performance appraisal purposes can also be in congruence to the goals of the organization because it is vital for its effectiveness and enhancing productivity at individual level (Ikramullah et al., 2016; Ochoti, Maronga, Muathe, Nyabwanga, \& Ronoh, 2012). A study carried out by Rowland and Hall (2012) urged that employee satisfaction is closely related with the perceived fairness of the employees about performance appraisal system. Thus, a fair and just assessment of employees help fuel the performance of employee's efficiently (Rowland \& Hall, 2012). Performance appraisal procedures possibly bring significant advantages for employees as well as organization, where appraisal feedback can be used as a tool for setting goals to assess and improve job performance (Swanepoel, Botha, \& Mangonyane, 2014). So, it is imperative that to investigate more about performance appraisal dimensions such as goal setting and purposes, fairness and rating scale format that identify employee satisfaction effect on employee job performance in organization (Getnet et al., 2014). On the basis of mentioned literature we can lead to our preposition:

H4: Employee satisfaction moderates the relationship of performance appraisal and its dimension with employee job performance

\section{Conceptual framework}

This study has drawn this framework for employing it specifically in the perspective of performance appraisal and its dimensions i.e. Goal setting and purposes, fairness and ratings scale format with employee job performance. The studies of Levy and Williams (2004); Othman (2014) and Ishaq et al. (2009) served as foundation block for this study. The findings of their research demonstrated that performance appraisal along with its dimensions are connected to various behavioural outcomes which employee satisfaction and employee job performance. This research framework is established on the results and facts of past researchers studies which show that performance appraisal dimensions is associated with employee job performance and this relationship has been moderated by employee satisfaction positively. Procedural justice theory is linked with the fairness of the performance appraisal system. It means when employees perceived fairness in procedures regarding outcome distribution, rules and regulations and performance ratings ultimately he/she will be satisfied and perform better (Roch \& Shanock, 2006; Thibaut \& Walker, 1975). While on the other hand, goal-setting theory also gives a manage system of goals and performance. Goals have a constant impact on employee job performance and attitude in organizations and work setting (Locke \& Latham, 2002). 


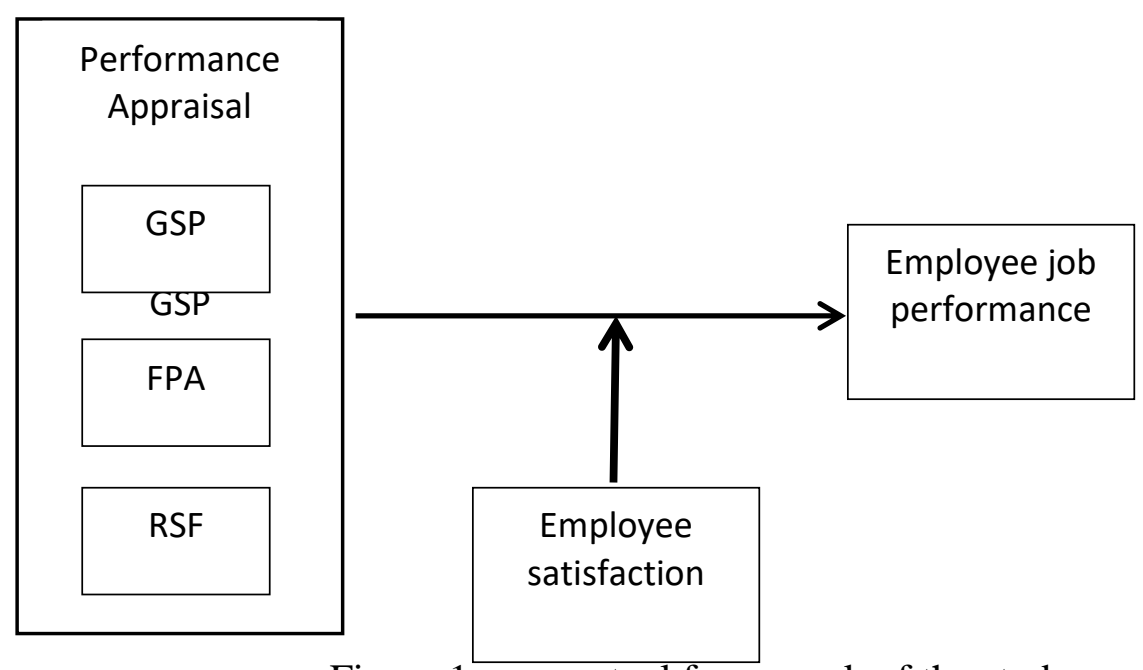

Figure 1: conceptual framework of the study

\section{Methodology}

In this article we already mentioned the dimensions of performance appraisal such as goal setting and purposes, fairness and rating scale format and the moderating effect of employee satisfaction on performance appraisal dimensions and employee job performance. Descriptive research design has been used in this research to identify the main problems related with the core factors of this study. The target population of this study was the faculty members of the public sector universities of Pakistan. Hence this design is appropriate for this study because the aim was to investigate the relationship among these variables and also the effect of independent variables on the dependent variables in the presence of moderating effect of employee satisfaction. In this study simple random sampling technique was used to give equal representation and opportunity of selection to each item of population. Among the target population 300 sample sizes have been selected for further analysis. Self-administered questionnaire has been used to collect the data from the respondents. The instruments used for data collection has been adopted from the study of (Greenberg, 1986; Ikramullah et al., 2016; Othman, 2014). The cronbach's alpha reported for goal-setting and purposes is 0.729 with scale of five items has been used. Fairness was also measured with six items having cronbach's alpha coefficient of 0.813 . While, cronbach's alpha coefficient for rating scale format, employee satisfaction and employee job performance was reported as $0.747,0.82$ and 0.83 with having six items, five items and five items respectively.

\subsection{Data analysis}

SPSS-23 and SmartPLS 3.2.6 was used to analyze the data. For the assessment of the model structure equation modeling was applied. PLS-SEM can allow the researcher to examine both the measurement model for construct validity and reliability and structural model for path analysis and hypothesis testing. According to Haenlein and Kaplan (2004) PLS-SEM aims to identify the theoretical model statistically in order to get both the theoretical and practical conclusions.

\subsection{Measurement model}

This model is used to investigate the links between the underlying variable and its items. Reflective and formative variables can be assessed with the help of measurement model. The essential requirement for checking measurement model is to examine both reflective and formative constructs (Hair, Ringle, \& Sarstedt, 2013). The cronbach's alpha limit for each construct is 0.70 (Hair, 2010). The constructs of this research have obtained the threshold limit of 0.70 . The same value of 0.70 has been noted as the recommended value for composite reliability in social science research (Picón, Castro, \& Roldán, 2014). The constructs of this study also fulfilled the required limit of 0.70 for composite reliability. For constructs validity verification both convergent and discriminant validity should be measured. Convergent validity can be examined through measuring factor loadings, AVE and CR. All the indicators involved in this study have attain the factor loading value of above 0.6 , and each variable also get the acceptable value 
of 0.5 for AVE and 0.7 for CR. While, for measuring discriminant validity two methods can be used i.e. Fornell-Larcker criteria and Heterotrait-Monotrait HTMT. The acceptable limit for HTMT is noted upto 0.90 (Henseler, Ringle, \& Sarstedt, 2015). All the values of HTMT fall in the range below 0.90. Though, this study meets the requirements of both the Fornell and Larcker criteria and HTMT ration for measuring discriminant validity of measurement model. The results for factor loadings, AVE and CR can be seen in Table 1. While, Table 2 shows Fornell-Larcker criteria and Table 3 reveals HTMT findings.

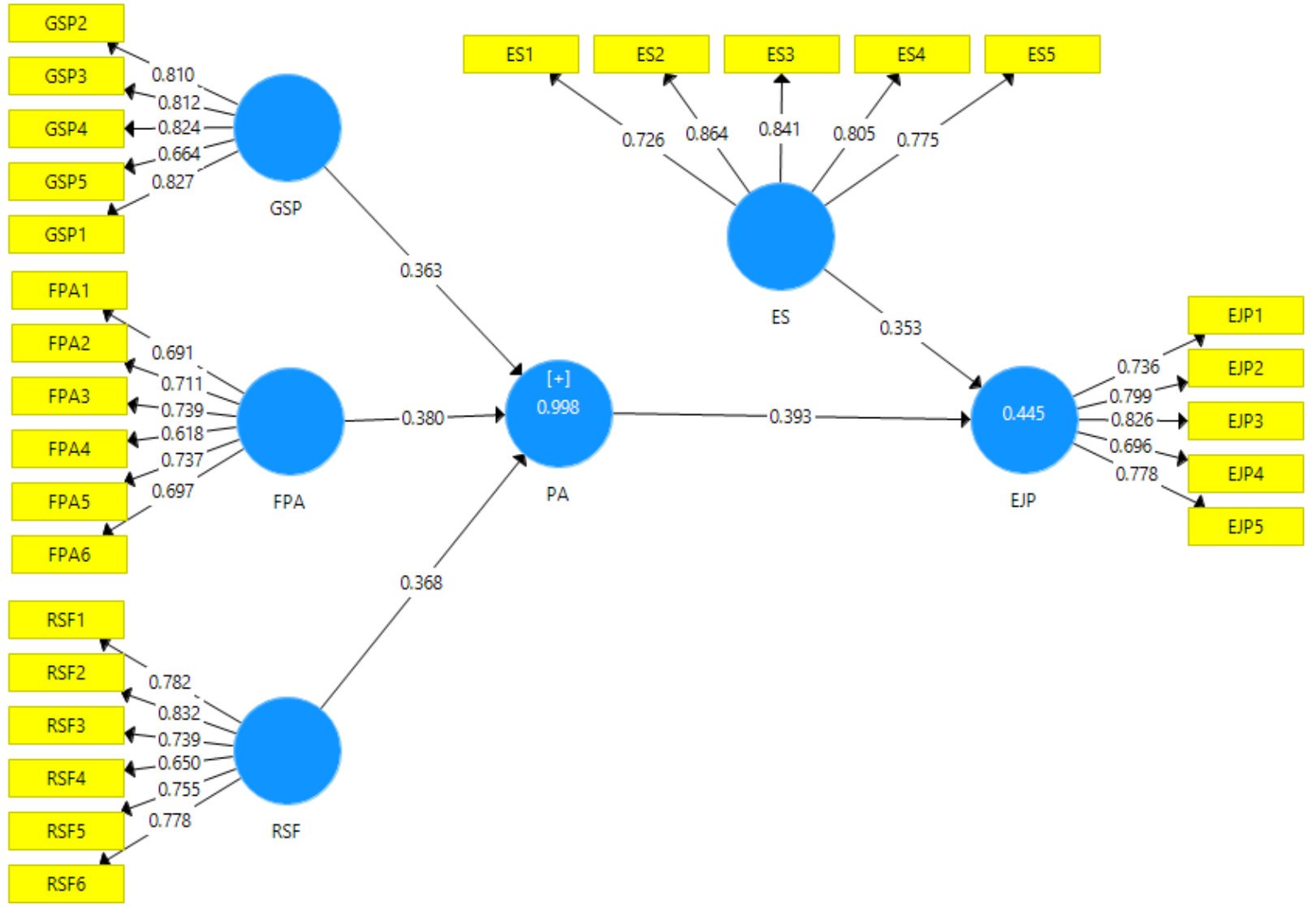

Figure 2: Measurement model Factor loadings, path coefficient and $\mathrm{R}^{2}$ values of constructs

TABLE 1: VARIABLES RELIABILITY AND VALIDITY

\begin{tabular}{|c|c|c|c|c|c|}
\hline Variables & Indicators & Factor loadings & AVE & CR & $\begin{array}{l}\text { Cronbach's } \\
\text { alpha }\end{array}$ \\
\hline $\begin{array}{l}\text { Goal setting and } \\
\text { purposes }\end{array}$ & $\begin{array}{l}\text { GSP1 } \\
\text { GSP2 } \\
\text { GSP3 } \\
\text { GSP4 } \\
\text { GSP5 }\end{array}$ & $\begin{array}{l}0.827 \\
0.810 \\
0.812 \\
0.824 \\
0.664\end{array}$ & 0.624 & 0.888 & 0.787 \\
\hline Fairness & $\begin{array}{l}\text { FPA1 } \\
\text { FPA2 } \\
\text { FPA3 } \\
\text { FPA4 } \\
\text { FPA5 } \\
\text { FPA6 }\end{array}$ & $\begin{array}{l}0.691 \\
0.711 \\
0.739 \\
0.618 \\
0.737 \\
0.697\end{array}$ & 0.50 & 0.850 & 0.841 \\
\hline $\begin{array}{c}\text { Rating scale } \\
\text { format }\end{array}$ & $\begin{array}{l}\text { RSF1 } \\
\text { RSF2 } \\
\text { RSF3 } \\
\text { RSF4 } \\
\text { RSF5 } \\
\text { RSF6 }\end{array}$ & $\begin{array}{l}0.782 \\
0.832 \\
0.739 \\
0.650 \\
0.755 \\
0.778\end{array}$ & 0.574 & 0.847 & 0.847 \\
\hline $\begin{array}{l}\text { Employee } \\
\text { satisfaction }\end{array}$ & $\begin{array}{l}\text { ES1 } \\
\text { ES2 }\end{array}$ & $\begin{array}{l}0.726 \\
0.864\end{array}$ & 0.664 & 0.900 & 0.861 \\
\hline
\end{tabular}




\begin{tabular}{|c|c|c|c|c|c|}
\hline & $\begin{array}{l}\text { ES3 } \\
\text { ES4 } \\
\text { ES5 }\end{array}$ & $\begin{array}{l}0.841 \\
0.805 \\
0.775 \\
\end{array}$ & & & \\
\hline $\begin{array}{l}\text { Employee job } \\
\text { performance }\end{array}$ & $\begin{array}{l}\text { EJP1 } \\
\text { EJP2 } \\
\text { EJP3 } \\
\text { EJP4 } \\
\text { EJP5 }\end{array}$ & $\begin{array}{l}0.736 \\
0.799 \\
0.826 \\
0.696 \\
0.778\end{array}$ & 0.581 & 0.877 & 0.824 \\
\hline
\end{tabular}

Table 2: Fornell-Larcker criteria

\begin{tabular}{|c|c|c|c|c|c|}
\hline & GSP & FPA & RSF & ES & EJP \\
\hline GSP & 0.786 & & & & \\
\hline FPA & 0.578 & 0.840 & & & \\
\hline RSF & 0.561 & 0.515 & 0.772 & & \\
\hline ES & 0.553 & 0.543 & 0.730 & 0.709 & \\
\hline EJP & 0.647 & 0.775 & 0.723 & 0.732 & 0.801 \\
\hline
\end{tabular}

TABLE 3: HTMT RATIO OF THE VARIABLES

\begin{tabular}{|c|c|c|c|c|c|}
\hline & GSP & FPA & RSF & ES & EJP \\
\hline GSP & & & & & \\
\hline FPA & 0.892 & & & & \\
\hline RSF & 0.710 & 0.857 & & & \\
\hline ES & 0.643 & 0.652 & 0.805 & & \\
\hline EJP & 0.789 & 0.837 & 0.661 & 0.890 & \\
\hline
\end{tabular}

\subsection{Structural model assessment}

Structural model is used for examining the regression part of the model and also shows the relationship present between the latent variables. Specifically, it identifies both the direct and indirect association between the variables (Byrne, 1998). Structural model involves the path coefficient significance Tstatistics, effect size $\mathrm{f}^{2}$ and coefficient of determination $\mathrm{R}^{2}$. The main purpose of structural model is to test the hypotheses which are established on the basis of conceptual frame work in the study. Structured path model was tested for direct relationship of goal setting and purposes, fairness and rating scale format with employee job performance. While, the moderating effect of employee satisfaction was also tested to find out its effects on such relationship. The findings of the entire hypotheses are given in Table 4. 


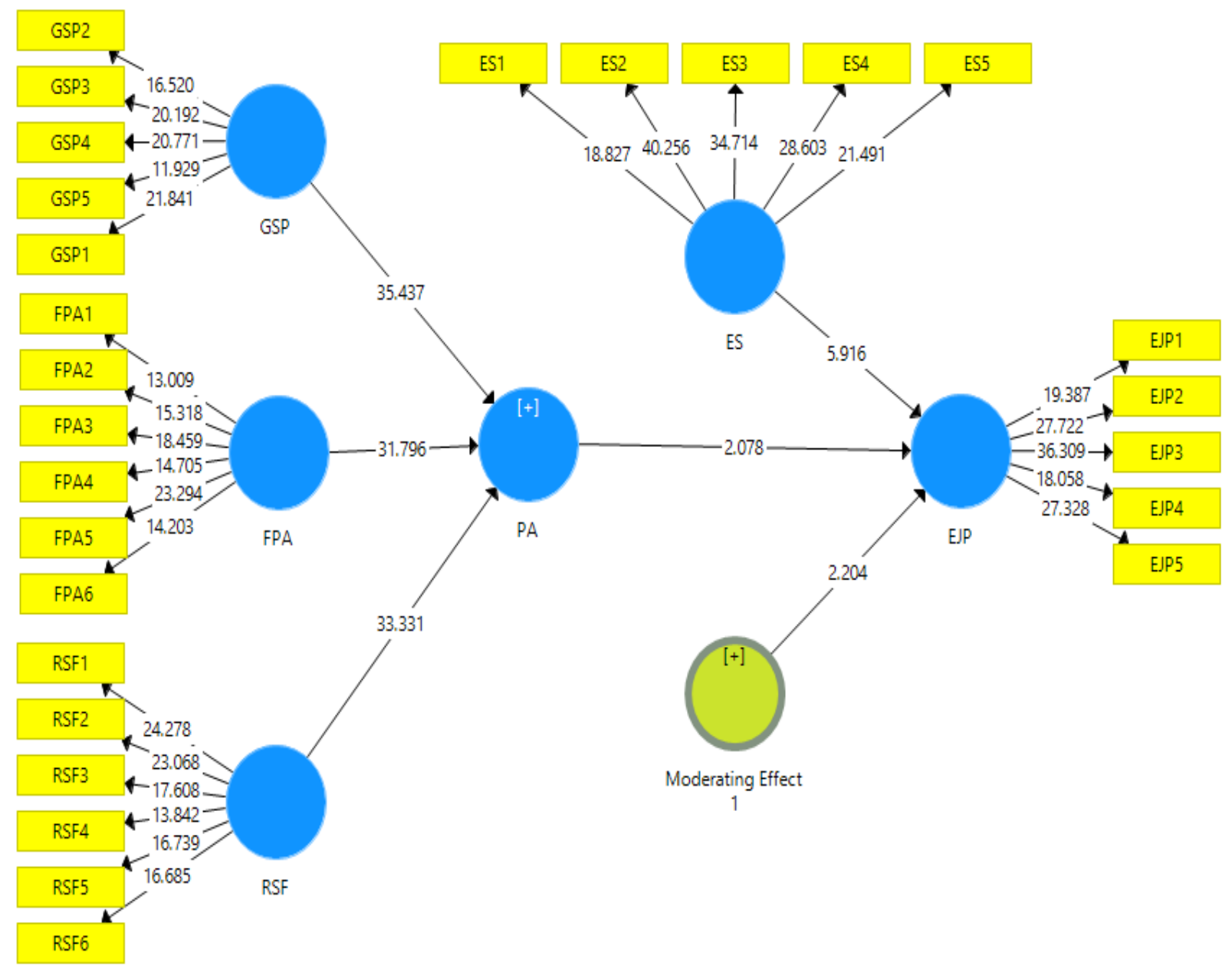

\section{Hypothesis testing}

HI: Goal setting and purposes has a significant effect on employee job performance.

We investigate the effect of goal setting and purposes on employee job performance in target population of the study. The beta coefficient between the constructs is 0.114 and found significant with t-value $=$ 5.912 (See Figure 1). This value enhances 0.114 unit increase in employee job performance. Hence it is concluded that goal setting and purposes has a positive and significant effect on employee job performance.

H2: Fairness has a significant effect on employee job performance.

The researcher analyzed the effect of fairness in the performance appraisal on employee job performance among the faculty members. From the results is revealed that beta coefficient of fairness to employee job performance is reported 0.194 with t-statistic $=6.148$. Therefore, it is drawn from the results that fairness has a positive and significant effect on employee job performance which is verified by the statistical data. H3: Rating scale format has a significant effect employee job performance.

In this hypothesis the researcher analyzed the effect of rating scale format on employee job performance among the target population. From the findings it is shown that beta coefficient of rating scale format to employee job performance is 0.193 with t-statistic $=7.276$ Thus, it is drawn from the outcomes of this hypothesis that rating scale format has positive and significant effect on employee job performance.

H4: Employee satisfaction moderates the relationship of performance appraisal and its dimension with employee job performance.

In hypothesis $\mathrm{H} 4$ the researcher examined the moderating effect of employee satisfaction on the relationship of performance appraisal and its dimensions with employee job performance in the target population. According to the best knowledge of researcher the moderating effect of employee satisfaction on such relationship has not yet explored. From the Table it can be concluded that employee satisfaction moderates the relationship between performance appraisal and its dimensions and employee job 
performance. Moderating effect of employee job performance path coefficient is -0.115 with having Tstatistics is 2.204 and found significant. It clearly reveals that employee satisfaction moderates such relationship among the target population.

Table 4: structural model beta coefficient and its significance

\begin{tabular}{|c|c|c|c|c|c|}
\hline & $\begin{array}{l}\text { Original } \\
\text { Sample (O) }\end{array}$ & $\begin{array}{l}\text { Sample Mean } \\
\text { (M) }\end{array}$ & $\begin{array}{l}\text { Standard } \\
\text { Deviation } \\
\text { (STDEV) }\end{array}$ & $\begin{array}{l}\text { T Statistics } \\
(|\mathrm{O} / \mathrm{STDEV}|)\end{array}$ & P Values \\
\hline ES -> EJP & 0.355 & 0.363 & 0.061 & 5.916 & 0.000 \\
\hline FPA -> PA & 0.38 & 0.381 & 0.012 & 31.796 & 0.000 \\
\hline GSP -> PA & 0.363 & 0.363 & 0.012 & 35.437 & 0.000 \\
\hline $\begin{array}{l}\text { Moderating Effect } 1 \text {-> } \\
\text { EJP }\end{array}$ & -0.112 & -0.115 & 0.015 & 2.204 & 0.028 \\
\hline PA -> EJP & 0.213 & 0.201 & 0.130 & 2.078 & 0.038 \\
\hline RSF -> PA & 0.368 & 0.369 & 0.012 & 33.331 & 0.000 \\
\hline FPA -> PA -> EJP & 0.192 & 0.194 & 0.015 & 6.148 & 0.000 \\
\hline GSP -> PA -> EJP & 0.113 & 0.114 & 0.081 & 5.912 & 0.000 \\
\hline RM $>>$ PA $->$ EJP & 0.114 & 0.115 & 0.091 & 4.975 & 0.000 \\
\hline RSF -> PA -> EJP & 0.192 & 0.193 & 0.081 & 7.276 & 0.000 \\
\hline
\end{tabular}

The coefficient of determination $\mathrm{R}^{2}$ values is also under the range of acceptable limit which is $0.75,0.50$ and 0.25 which reveals strong, moderate and weak associations (Chin, 2010). The value of performance appraisal is noted to be 0.998 which means that strong effect of $98 \%$ has been caused in performance appraisal due to its dimensions such as goal setting and purposes, fairness and rating scale format. While, $\mathrm{R}^{2}$ value reported for employee job performance is 0.445 reflected moderate and it shows that $44 \%$ variance is caused in employee job performance due to its independent variables.

Table 5: Coefficient of determination $\mathrm{R}^{2}$

\begin{tabular}{|c|c|}
\hline Dependent variables & $\mathrm{R}^{2}$ \\
\hline Performance appraisal & 0.445 \\
\hline Employee job performance & 0.998 \\
\hline
\end{tabular}

\section{Discussion}

This research concentrates on the effect of performance appraisal dimensions like goal setting and purposes, fairness and rating scale format on employee job performance and paying attention to the moderating effect of employee satisfaction on such relationship. The obtained findings display that all the three dimensions of performance appraisal has a strong positive and significant effect on employee job performance among the faculty members in the public sector universities of Pakistan. All the hypotheses were fully supported by the empirical data. If performance appraisal is goal oriented, just, fair and having valid and reliable rating scale format employees will be satisfied with procedures and performance ratings and resultantly their individual performance will be enhanced positively. This study finding is in accordance with the previous studies of (Getnet et al., 2014; Muhammad Asad khan, 2018; Terpstra \& Rozell, 1994).

\section{Conclusion, limitations and future research}

This article aims to respond questions: whether goal setting and purposes, fairness and rating scale format of performance appraisal have a significant effect on employee job performance and also to examine the moderating effect of employee satisfaction on such relationship. A conceptual model was formulated with five identified constructs and the development of three hypotheses. The result of the empirical study 
proposed that the four hypotheses tested are found valid and reliable and are proved in their organization. The respondents of the study unanimously responded that performance appraisal dimensions such as goal setting and purposes, fairness and rating scale format has a significnat impact on employee job performance. Furthermore, the respondents were also found agreed on the moderating effect of employee satisfaction on such relationship.

Results of this study are in congruence with procedural justice theory and goal setting thory that if performance appraisal is fair, just, goal oriented and rating scale format is valid and reliable. No doubt employees will be satisfied and get motivated to enhance their own job performance effectively. High employee satisfaction is efficient in a way to advance employee job performance which is necessary for organizational success. If the faculty members of universities are given fair rating and goal achiever performance appraisal system it can not only increase their motivation and satisfaction but also found to be helpful in increasing individual performance and organizational performance. The current study adds significant literature to the existing realm of knowledge and the findings can also be used in those countries which have a very rare research in this field. This study also opens new ways of directions and facets in the area of management by imitating debates on the importance of employee satisfaction as a moderator in the relationship of performance appraisal dimensions and employee job performance among faculty members.

Certain limitations also carries with this study in which the first one is no such study has been conducted in public sector universities of Pakistan. So, future researcher could also select private universities for validation of these results. Due to time and resources constraint we have not done our research thoroughly to assess other important aspects that influence performance appraisal system and employee job performance of employees. So the future researcher can also add other variables i.e. empowerment, job design, and leadership style to improve employee job performance.

\section{References}

Abbas, M. Z. (2014). Effectiveness of performance Appraisal on performance of employees. JOSR Journal of Business and Management, 173-178.

Byrne, B. M. (1998). Structural equation modeling with LISREL. Prelis, and Simplis, 196-199.

Campbell, J. P., McCloy, R. A., Oppler, S. H., \& Sager, C. E. (1993). A theory of performance. Personnel selection in organizations, $3570,35-70$.

Chin, W. W. (2010). How to write up and report PLS analyses Handbook of partial least squares (pp. 655-690): Springer.

Cintrón, R., \& Flaniken, F. (2011). Performance appraisal: A supervision or leadership tool. International Journal of Business and Social Science, 2(17), 29-37.

DeNisi, A. S. (2011). Managing performance to change behavior. Journal of Organizational Behavior Management, 31(4), 262-276.

Djurdjevic, E., \& Wheeler, A. R. (2014). A dynamic multilevel model of performance rating Research in personnel and human resources management (pp. 147-176): Emerald Group Publishing Limited.

Embi, M. A., \& Choon, L. K. (2014). Rater's Intention Towards Appraising Accurately. Jurnal Studi Pemerintahan, 5(2).

Getnet, B., Jebena, T., \& Tsegaye, A. (2014). The effect of employee's fairness perception on their satisfaction towards the performance appraisal practices (A case study of University of Gondar). International Journal of Management and Commerce Innovations, 2(1), 174-210.

Greenberg, J. (1986). Determinants of perceived fairness of performance evaluations. Journal of applied psychology, 71(2), 340.

Haenlein, M., \& Kaplan, A. M. (2004). A beginner's guide to partial least squares analysis. Understanding statistics, 3(4), 283-297.

Hair, J. F. (2010). Black, WC, Babin, BJ, \& Anderson, RE (2010). Multivariate data analysis, 7.

Hair, J. F., Ringle, C. M., \& Sarstedt, M. (2013). Partial least squares structural equation modeling: Rigorous applications, better results and higher acceptance. 
Henseler, J., Ringle, C. M., \& Sarstedt, M. (2015). A new criterion for assessing discriminant validity in variance-based structural equation modeling. Journal of the academy of marketing science, 43(1), 115-135.

Ikramullah, M., Shah, B., Hassan, F. S. U., Zaman, T., \& Khan, H. (2011). Fairness perceptions of performance appraisal system: An empirical study of civil servants in district Dera Ismail Khan, Pakistan. International Journal of Business and Social Science, 2(21).

Ikramullah, M., Van Prooijen, J.-W., Iqbal, M. Z., \& Ul-Hassan, F. S. (2016). Effectiveness of performance appraisal: Developing a conceptual framework using competing values approach. Personnel Review, 45(2), 334-352.

Ilgen, D. R., \& Schneider, J. (1991). Performance measurement: A multi-discipline view. International review of industrial and organizational psychology, 6, 71-108.

Iqbal, N., Ahmad, N., \& Haider, Z. (2013). Impact of Performance Appraisal on Employee's Performance Involving the Moderating Role of Motivation $\backslash$ Oman Chapter of Arabian Journal of Business and Management Review.-2013, Vol. 3, No. 1: Sohar University.

Iqbal, N., Ahmad, N., Haider, Z., \& Batool, Y. (2013). Impact of performance appraisal on employee's performance involvingthe Moderating Role of Motivation. Arabian Journal of Business and Management Review (OMAN Chapter), 3(1), 37.

Ishaq, H. M., Iqbal, M. Z., \& Zaheer, A. (2009). Effectiveness of performance appraisal: Its outcomes and detriments in Pakistani Organizations. European journal of social sciences, 10(3), 479-485.

Jawahar, I. (2007). The influence of perceptions of fairness on performance appraisal reactions. Journal of Labor Research, 28(4), 735-754.

Kaleem, M. M., Jabeen, B., \& Twana, M. J. (2013). Organizational Justice in Performance Appraisal System: Impact on Employees Satisfaction and Work Performance. Studies, 2(2), 28-37.

Keeping, L. M., \& Levy, P. E. (2000). Performance appraisal reactions: Measurement, modeling, and method bias. Journal of applied psychology, 85(5), 708.

Khan, M. F. U. (2013). Role of performance appraisal system on employees motivation. IOSR Journal of business and management, 8(4), 66-83.

Khan, R. (2014). The Impacts of Goal Setting and Curiosity on the Employee Job Performance: A Perspective from NGO sector of Pakistan. Management Studies and Economic Systems, 1(1), 3340.

Kline, T. J., \& Sulsky, L. M. (2009). Measurement and assessment issues in performance appraisal. Canadian Psychology/Psychologie canadienne, 50(3), 161.

Knight, D., Durham, C. C., \& Locke, E. A. (2001). The relationship of team goals, incentives, and efficacy to strategic risk, tactical implementation, and performance. Academy of Management Journal, 44(2), 326-338.

Landy, F. J., \& Farr, J. L. (1983). The measurement of work performance: Methods, theory, and applications: Academic Press.

Lawler III, E. E., Benson, G. S., \& McDermott, M. (2012). What makes performance appraisals effective? Compensation \& Benefits Review, 44(4), 191-200.

Levy, P. E., \& Williams, J. R. (2004). The social context of performance appraisal: A review and framework for the future. Journal of management, 30(6), 881-905.

Locke, E. A., \& Latham, G. P. (2002). Building a practically useful theory of goal setting and task motivation: A 35-year odyssey. American psychologist, 57(9), 705.

Muhammad Asad khan, F. B. I., Rosman MD Yusoff, Altaf Hussain,Fazlulaini Binti Mohd Yunus. (2018). The Impact of Performance Appraisal on Employee Job Performance in Public Sector Universities of Khyber Pakhtunkhwa, Pakistan. International Journal of Engineering \& Technology, 7 ((3.25)), 544-548.

Ochoti, G. N., Maronga, E., Muathe, S., Nyabwanga, R. N., \& Ronoh, P. K. (2012). Factors influencing employee performance appraisal system: a case of the ministry of state for provincial administration \& internal security, Kenya. International Journal of Business and Social Science, $3(20)$. 
Othman, N. (2014). Employee Performance Appraisal Satisfaction: The Case Evidence from Brunei's Civil Service.

Palaiologos, A., Papazekos, P., \& Panayotopoulou, L. (2011). Organizational justice and employee satisfaction in performance appraisal. Journal of European Industrial Training, 35(8), 826-840.

Picón, A., Castro, I., \& Roldán, J. L. (2014). The relationship between satisfaction and loyalty: A mediator analysis. Journal of Business Research, 67(5), 746-751.

Pulakos, E. D. (2004). Performance Management: A roadmap for developing, implementing and evaluating performance management systems: SHRM foundation.

Rahman, W. (2012). The Relationship of Attitudinal and Behavioural Outcomes with Employee Development in the Context of Performance Appraisal in Public Universities of Khyber Pakhtunkhwa. PhD Academic), National University of Moderen Langauges, Islamabad.

Roch, S. G., \& Shanock, L. R. (2006). Organizational justice in an exchange framework: Clarifying organizational justice distinctions. Journal of management, 32(2), 299-322.

Rowland, C. A., \& Hall, R. D. (2012). Organizational justice and performance: is appraisal fair? EuroMed Journal of Business, 7(3), 280-293.

Sahai, S., \& Srivastava, A. (2012). Goal/target setting and performance assessment as tool for talent management. Procedia-Social and Behavioral Sciences, 37, 241-246.

Selvarajan, R., \& Cloninger, P. A. (2009). The influence of job performance outcomes on ethical assessments. Personnel Review, 38(4), 398-412.

Shahzad, K., Bashir, S., \& Ramay, M. I. (2008). Impact of HR practices on perceived performance of university teachers in Pakistan. International review of business research papers, 4(2), 302-315.

Simmons, J. (2002). An "expert witness" perspective on performance appraisal in universities and colleges. Employee Relations, 24(1), 86-100.

Smith, P. C., \& Kendall, L. M. (1963). Retranslation of expectations: An approach to the construction of unambiguous anchors for rating scales. Journal of applied psychology, 47(2), 149.

Sudin, S. (2011). Fairness of and satisfaction with performance appraisal process. Journal of Global Management, 2(1), 66-83.

Swanepoel, S., Botha, P. A., \& Mangonyane, N. B. (2014). Politicisation of performance appraisals. SA Journal of Human Resource Management, 12(1), 1-9.

Teo, T. C., \& Low, K. C. P. (2016). The Impact of Goal Setting on Employee Effectiveness to Improve Organisation Effectiveness: Empirical Study of a High-Tech Company in Singapore.

Terpstra, D. E., \& Rozell, E. J. (1994). The relationship of goal setting to organizational profitability. Group \& Organization Management, 19(3), 285-294.

Thibaut, J. W., \& Walker, L. (1975). Procedural justice: A psychological analysis: L. Erlbaum Associates.

Tziner, A., \& Kopelman, R. E. (2002). Is there a preferred performance rating format? A non-psychometric perspective. Applied Psychology, 51(3), 479-503.

Zeb, A., Abdullah, N. H., \& Javaid, M. (2018). Impact of Human Capital Management Practices on Employees' Job Performance. Paper presented at the Journal of Physics: Conference Series.

Zheng, W., Zhang, M., \& Li, H. (2012). Performance appraisal process and organizational citizenship behavior. Journal of managerial psychology, 27(7), 732-752.

Zia-ur-Rehman, M., Faisal, H., \& Khan, R. A. (2015). In Public Sector Organizations, how the Performance of Employees is influenced by the HR Practices-Analyzing the Perspective. Journal of Managerial Sciences, 9(1). 